Mini Review

\title{
Magnetic Particles in Electrochemical Analyses
}

\author{
Miroslav Pohanka \\ Faculty of Military Health Sciences, University of Defence, Trebesska 1575, CZ-500 01 Hradec \\ Kralove, Czech Republic \\ E-mail: miroslav.pohanka@gmail.com
}

doi: $10.20964 / 2018.12 .259$

Received: 23 August 2018 / Accepted: 8 September 2018 / Published: 5 November 2018

\begin{abstract}
Magnetic particles are an actual tool which has multiple use in many subjects including industrial processes, chemical separation, analytical chemistry and medicine. The major progress in this field has been made in the last few years. In this mini review, specific field of electrochemical analyses is surveyed and description of new methods where magnetic particles play a significant role is elucidated. Discussion about the current electrochemical protocols written in the current literature and expectation for the next development of biosensors construction, portable sensor systems and electrochemical methods where magnetic particles are a vital part necessary for analyte isolation is given here.
\end{abstract}

Keywords: affinity; amperometry; antibody; biosensor; biorecognition; immunochemistry; immunoglobulin; label free assay; piezoelectric; quartz crystal microbalance; voltammetry

\section{$\underline{\text { FULL TEXT }}$}

(C) 2018 The Authors. Published by ESG (www.electrochemsci.org). This article is an open access article distributed under the terms and conditions of the Creative Commons Attribution license (http://creativecommons.org/licenses/by/4.0/). 